\title{
Sustainability of sweet orange (Citrus sinensis) peel meal on the performance of finisher broilers
}

\author{
E. O. Ahaotu ${ }^{\star}$, B. U. Ekenyem ${ }^{2}$ and E. Aggrey ${ }^{1}$ \\ 1Department of Animal Production Technology, Imo State Polytechnic Umuagwo, Nigeria. \\ ${ }^{2}$ Department of Animal Science and Fisheries, Imo State University Owerri, Nigeria.
}

*Corresponding author. Email: emmaocy@yahoo.com

Copyright (9) 2017 Ahaotu et al. This article remains permanently open access under the terms of the Creative Commons Attribution License 4.0, which permits unrestricted use, distribution, and reproduction in any medium, provided the original work is properly cited.

Received 21st December, 2016; Accepted 15th February, 2017

\begin{abstract}
Two-hundred (200) four weeks old broiler chickens of Anak 2000 breed from Imo State Polytechnic Research farm were used to investigate the effect of sweet orange peel meal in broiler rations. The birds were fed on $0 \%, 2.50 \%, 5.00 \%, 7.50 \%$ and $10.00 \%$ dietary inclusion of sweet orange peel meal as replacement for wheat offals in a 28 day feeding trial. Significant difference between dietary levels of sweet orange peel meal and wheat offals were observed on feed efficiency and weight gain $(\mathrm{p}<0.05)$. Increase in dietary levels of sweet orange peel meal reduced feed transit time in gastro-intestinal tract $(\mathrm{GIT})(\mathrm{p}<0.05)$ while supplementary wheat offal had the opposite effect $(p<0.05)$. It was concluded that broiler chickens could tolerate up to $7.50 \%$ dietary levels of sweet orange peel meal without wheat offal added to such a diet, performance was comparable to that of birds fed a standard diet with money saved in the process.
\end{abstract}

Key words: Broiler, feed efficiency, performance, sweet orange peel meal, wheat offal.

\section{INTRODUCTION}

The poultry industry is one of the fast means of providing the much needed animal protein to the teeming populace. It has been suggested that the expansion of the Nigeria poultry holds the greatest promise of bridging the animal protein gap in the country within the shortest possible time (Coloiet al., 2009; Ahaotu, 1999). Some agroindustrial by-products like Bambara nut, feather meal, rice offal, brewer's dried grain have been used in poultry diets to replace cereals (Ahaotu et al., 2016a, b; Ahaotu et al, 2010; Ahaotu et al., 2012). Broiler birds are probably the most universal and important of all poultry as producers of meat for human consumption. It has been reported that sweet orange (Citrus sinensis) peel meal obtained from ground sun dried peels can replace dietary maize in broiler chicken diet at $20 \%$ level without any adverse effect on performance (Agu, 2006, Grant, 2007; Baird et al., 1974). Feed processing helps to enhance the feeding quality of agro-industrial by-products by reducing the level of toxicants where present, improving their nutrient value, acceptability of feed, and utilization by animals.

The shortage of good quality feeds needed to sustain livestock growth, especially during the dry season has been a major challenge to the industry in the developing countries. Thus crop residues, agro-industrial by products and non-conventional feed resources which abound during the dry season are being evaluated to access their nutritive potential to support livestock productivity. Several factors have been generally identified as limiting to the utilization or high incorporation of non-conventional feedstuffs in livestock feed. These include low protein content, high fibre, amino acid imbalance and presence of anti-nutritional factors (Mourao et al., 2008; Gohl, 1981). Anti-nutritional factors have significant negative effects on livestock production. These effects include reduction in palatability, digestibility and utilization of ration, intoxication of different classes of livestock, resulting in mortality or decreased production of animal and reduction in the quality of meat, egg, and milk products due to the presence of hazardous residues 
(Nazok et al., 2010).

A number of four agro-based products are generated from fresh citrus after the main products of interest have been removed or extracted during processing or peeled for direct human consumption as in the case of developing countries. Clusters of peel of the sweet orange are usually noticed on streets and along major roads in Nigeria because government and orange retailers have no strategic disposal programme thus becoming an environmental problem. Ipinjolu (2000) has suggested that rather than discarding the orange peels, they can be sun-dried and then milled in grinding machine to fine particle to obtain the orange peel meal which can be included in fish diets. Sweet orange fruit peel meal has been observed to be a source of calorie and protein comparable with maize (Aggery, 2013). The peel contains oil sacs and the oil is composed of 91 to $94 \%$ d-limonene and 2.0 to $2.1 \% \beta$-myrcene as a minor constituent (Florou-Paneri et al., 2001). Poly-mentholated flavones are also a class of compounds found in citrus peel and produce no negative side effects in the animals fed the poly-mentholated flavones containing diets (Florou-Paneri et al., 2001).

In poultry production, feed cost also claims the largest share of the total expenses involved in the production process. Feed alone accounts for over $75 \%$ of the total cost of production, out of which $50 \%$ is expended on protein and energy sources (Ahaotu et al., 2012). The unavailability and expensive nature of cereals (maize and sorghum) stemming directly from its use as staple human food as well as major feed ingredients in Nigeria creates the problem of rising feed costs. This unprecedented increase in the cost of feed has made the price of poultry products beyond the reach of the average Nigerian (Ahaotu et al., 2011). The solution naturally, is to increase the production of these cereals commonly used in poultry feed so as to cater for the needs both man and his livestock (Ahaotu and Ekenyem, 2009). But, as this cannot work owing to the continuous increase in human and livestock production, attempts should be made to replace these expensive energy supplements in poultry feeds with man conventional and cheaply sourced ingredients so as to sustain the efficiency and profitability of poultry industry (Ahaotu et al., 2010, Madubuike et al., 2003).

The utilization and incorporation of sweet orange peel meal into broiler feed will go a long way in increasing broiler production. Hence, this study therefore investigated the effect of the fermentation of fresh sweet orange fruit peel on its maize replacement value in broiler chickens.

\section{MATERIALS AND METHODS}

The experiment was carried out at the Imo State Polytechnic Teaching and Research Farm Umuagwo,
Table 1. Chemical composition of SOPM (Sweet Orange Peel Meal).

\begin{tabular}{lc}
\hline Chemical Compositions & Percentage (\%) \\
\hline Dry Matter Content & 96.22 \\
Crude Protein & 7.71 \\
Crude Fiber & 9.58 \\
Ether Extract & 2.11 \\
Ash & 5.12 \\
Nitrogen Free Extract & 71.24 \\
Metabolisable Energy & $3752.12 \mathrm{Kcal} / \mathrm{Kg}$ \\
& \\
Elemental analysis & \\
Calcium & 3.30 \\
Phosphorus & 2.30 \\
Iron & 0.40 \\
VITAMIN ANALYSIS & $1 . U$ \\
Ascorbic Acid & 49.00 \\
Thiamine & 0.08 \\
Riboflavin & 0.03 \\
Niacin & 0.20 \\
\hline
\end{tabular}

Owerri, Imo State, Nigeria. The site is situated between longitudes $7^{\circ} 0^{1} 06^{11} \mathrm{E}$ and $7^{\circ} 03^{1} 00^{11}$ and latitudes $5^{\circ} 28^{1}$ $00^{11} \mathrm{~N}$ and $5^{\circ} 30^{1} 00^{11} \mathrm{~N}$ in the humid tropical West Africa (IMLS, 2009). Sweet orange peel used for this study was collected from Eke -Ukwu Market, Owerri, Imo State, Nigeria. The peels were spread on mat and concrete floor to be dried by solar radiation. This was done at the first week of December when the relative humidity was low, temperature high and accompanied by dry harmattan wind. On drying, the samples were milled. The processed sweet orange peel meal was subjected to proximate analysis (Table 1) at the Science Technology Laboratory, Imo State Polytechnic Umuagwo, Nigeria, using standard methods (AOAC, 2001). The mineral analysis was carried out using the methods of Grueling (2000) while gross energy was determined with a Gallen Pump Oxygen Adiabatic Bomb Calorimeter. The samples were also weighed, evaporated in rotary evaporator and then loaded into the Technicon sequential multi sample Analyzer for amino acid determination as described by Spackman et al., (1958).

\section{Chemical composition and Nutrition value}

The proximate composition of Sweet orange peel meal (SOPM) is shown in Table 1.

\section{Procurement of experimental Birds and Brooding}

Two hundred and twenty (220) four weeks old chickens (Anak 2000 broilers) brooded in the brooder house of the 
Table 2. Ingredient composition of Broiler finisher diets.

\begin{tabular}{lccccc}
\hline \multirow{2}{*}{ Ingredients } & \multicolumn{5}{c}{ Varying Levels of Replacement } \\
\cline { 2 - 6 } & $\mathbf{T}_{\mathbf{1}}$ & $\mathbf{T}_{\mathbf{2}}$ & $\mathbf{T}_{\mathbf{3}}$ & $\mathbf{T}_{\mathbf{4}}$ & $\mathbf{T}_{\mathbf{5}}$ \\
\hline Maize & 35 & 35 & 35 & 35 & 35 \\
Fish Meal & 2 & 2 & 2 & 2 & 2 \\
Soya full fat & 18 & 18 & 18 & 18 & 18 \\
Wheat Offal & 10.00 & 7.50 & 5.00 & 2.50 & 0.00 \\
Sweet Orange peel meal & 0.00 & 2.50 & 5.00 & 7.50 & 100 \\
Rice bran & 11.00 & 11.00 & 11.00 & 11.00 & 11.00 \\
Palm kernel cake & 20.00 & 20.00 & 20.00 & 20.00 & 20.00 \\
Bone meal & 4.32 & 4.32 & 4.32 & 4.32 & 4.32 \\
Lysine & 0.08 & 0.08 & 0.08 & 0.08 & 0.08 \\
Methionine & 0.05 & 0.05 & 0.05 & 0.05 & 0.05 \\
Common salt & 0.30 & 0.30 & 0.30 & 0.30 & 0.30 \\
*Premix (Broiler) & 0.25 & 0.25 & 0.25 & 0.25 & 0.25 \\
Total & 100.00 & 100.00 & 100.00 & 100.00 & 100.00 \\
Calculated C.P (\%) & 21.11 & 20.41 & 19.71 & 19.01 & 18.31 \\
Ether Extract (\%) & 4.87 & 5.18 & 5.49 & 5.81 & 6.13 \\
Crude Fiber (\%) & 3.59 & 4.25 & 4.90 & 5.55 & 6.20 \\
M.E (Cal/kg) & 2522.4 & 2518.7 & 2514.4 & 2511.2 & 2507.9 \\
\hline
\end{tabular}

*2.5kg Premix/tonne contain; Vitamin A 10,000 I.U; Vitamin D3 2000,000 I.U, Vitamin E 12,000 I.U. Vitamin K 2.5gm, Thiamine $1.5 \mathrm{~g}$, Riboflavin $5 \mathrm{~g}$, Pyriboflavin (B6) $1.5 \mathrm{~g}$, Vitamin B12 $10 \mathrm{mg}$, Biotin $2 \mathrm{mg}$, Niacin $15 \mathrm{~g}$, Pantothenic acid $5 \mathrm{~g}$, Zinc $50 \mathrm{~g}$, Iron $25 \mathrm{~g}$, Copper $5 \mathrm{~g}$, lodine $1.4 \mathrm{~g}$, Selenium $100 \mathrm{mg}$, Cobalt $300 \mathrm{mg}$, BHT. $125 \mathrm{~g}$.

Imo State Polytechnic Umuagwo, Owerri, Nigeria were used for the study. The birds were fed nutrient composition for one week to stabilize the birds before the feeding trial. Out of the lot, 200 four weeks broiler chickens were on basis of good health, apparent viability and good conformation assigned to four dietary treatments.

\section{Formulation of the experimental diets}

Five experimental diets were formulated containing $0 \%$, $2.50 \%, 5.00 \%, 7.50 \%$ and $10.00 \%$ SOPM representing treatments $1,2,3,4$ and 5 respectively in which $0 \%$ SOPM was the control (Table 2). The feed was fortified with vitamin premix and synthetic amino acid. The ingredients were thoroughly mixed to ensure homogeneity before grinding in a hammer mill. Experimental birds were randomly allocated to the four dietary groups containing $0,2.50,5.00,7.50$ and $10.00 \%$ SOPM for treatments $1,2,3,4$ and 5 and were replicated thrice in a completely randomized design. Four weeks old birds were reared on deep litter floor each pen measuring $3.5 \mathrm{~m} \times 3.5 \mathrm{~m}$. Each pen was equipped with feeding troughs and drinkers. Electric bulbs and kerosene lanterns alternated as sources of light. Treatment diets and water were administered ad libitum. Routine management practices such as vaccination, drug administration and scrupulous cleanliness of the pens and equipment were carefully applied.

\section{Data collection}

Initial weights were determined at the start of the experiment with the aid of salter weighing balance and thereafter at weekly intervals. The final weight was also taken by weighing the birds in each replicate on the last day of the experiment using the same weighing balance. The weight gains were calculated by subtracting the initial weight from the final weight. In addition, the feed intake was calculated by subtracting the feed remaining from the total feed supplied each day before serving fresh one. The feed conversion ratio was also calculated by dividing feed intake by weight gain. The feed cost was determined as the sum of the cost of all ingredients included in the diet.

\section{Data analysis}

All data generated were subjected to one way analysis of variance (Steel and Torrie, 1980), while significant differences in means were determined using Duncan's Multiple Range Test (Gordon and Gordon, 2004).

\section{RESULTS AND DISCUSSION}

Table 3 showed that final weight of the experimental birds varied significantly $(p<0.05)$ between treatments. Birds 
Table 3. Performance characteristics of Broiler finisher birds fed varying replacement levels of sweet orange peel meal for wheat offal.

\begin{tabular}{lcccccc}
\hline \multirow{2}{*}{ Parameters } & \multicolumn{5}{c}{ Varying levels of replacement } & \multirow{2}{*}{ SEM } \\
\cline { 2 - 6 } & T1 & T2 & T3 & T4 & T5 & \\
\hline Initial Live Weight (g) at 5th week & $700.12^{\mathrm{d}}$ & $652.4^{\mathrm{c}}$ & $641.15^{\mathrm{c}}$ & $591.56^{\mathrm{b}}$ & $564.28^{\mathrm{a}}$ & $1.90^{\star}$ \\
Final Live Weight (g) at 9th week & $1740^{\mathrm{e}}$ & $1400^{\mathrm{d}}$ & $1330^{\mathrm{c}}$ & $1080 \mathrm{~b}$ & $930^{\mathrm{a}}$ & $2.06^{\star}$ \\
Daily Weight Gain (g) & $42.16^{\mathrm{a}}$ & $41.08^{\mathrm{a}}$ & $38.29^{\mathrm{b}}$ & $38.20 \mathrm{~b}$ & $38.08^{\mathrm{b}}$ & $0.81^{\star}$ \\
Daily Feed Intake (g) & $89.69^{\mathrm{a}}$ & $95.68 \mathrm{~b}$ & $97.22^{\mathrm{b}}$ & $97.31 \mathrm{~b}$ & $99.34^{\mathrm{c}}$ & $0.72^{\star}$ \\
FCR & 2.61 & 2.87 & 3.17 & 3.19 & 3.2 & $0.56 \mathrm{~ns}$ \\
Cost of 1 kg of feed (\#) & $1.51^{\star}$ & $156.12^{\mathrm{a}}$ & $150.56^{\mathrm{b}}$ & $145.00 \mathrm{c}$ & $141.88^{\mathrm{d}}$ & $73.88^{\mathrm{e}}$ \\
Mortality & $1.00^{\mathrm{a}}$ & $1.00^{\mathrm{a}}$ & $1.00^{\mathrm{a}}$ & $1.00^{\mathrm{a}}$ & $4.00^{\mathrm{b}}$ & $0.04^{\star}$ \\
\hline
\end{tabular}

abcdemeans within the same row, having different superscripts are significantly different $(P<0.05)$. FCR, Feed Conversion Ratio.

Table 4. Carcass characteristics of Broiler chickens fed varying replacement levels of sweet orange peel meal for wheat offal.

\begin{tabular}{|c|c|c|c|c|c|c|}
\hline \multirow{2}{*}{ Parameters } & \multicolumn{5}{|c|}{ Varying levels of replacement } & \multirow{2}{*}{ SEM } \\
\hline & $\mathbf{T}_{1}$ & $\mathrm{~T}_{2}$ & $\mathrm{~T}_{3}$ & $\mathrm{~T}_{4}$ & $\mathbf{T}_{5}$ & \\
\hline Drum Stick (cm)* & $13.8^{a}$ & $12.8^{a}$ & $12.0^{b}$ & $11.5^{\mathrm{b}}$ & $11.3^{\mathrm{b}}$ & $1.22^{*}$ \\
\hline Wing length (cm) & $20.8^{a}$ & $20.5^{a}$ & $20.4^{\mathrm{a}}$ & $119.5^{\mathrm{b}}$ & $19.2^{\mathrm{b}}$ & $0.30^{*}$ \\
\hline Body length (cm) & $27.7^{a}$ & $26.4^{a}$ & $25.9^{\mathrm{b}}$ & $24.8^{b}$ & $24.8^{a}$ & $0.21^{*}$ \\
\hline Thigh length (cm) & $15.8^{\mathrm{a}}$ & $13.0^{\mathrm{c}}$ & $12.5^{c}$ & $11.48^{c}$ & $11.40^{\mathrm{c}}$ & $1.24^{*}$ \\
\hline Heart Girth $(\mathrm{cm})^{*}$ & $26.23^{a}$ & $26.00^{\mathrm{a}}$ & $24.32^{\mathrm{b}}$ & $22.64^{c}$ & $22.64^{c}$ & $0.44^{*}$ \\
\hline Live weight at $9^{\text {th }}$ week (gm) & $1742^{\mathrm{a}}$ & $1390^{\circ}$ & $1380^{c}$ & $1199^{b}$ & $950^{d}$ & $0.32^{*}$ \\
\hline Dress carcass Weight (gm) & $1480^{d}$ & $1376^{c}$ & $1245^{\mathrm{b}}$ & $1160^{b}$ & $920^{\mathrm{a}}$ & $0.11^{*}$ \\
\hline Eviscerated Weight (gm) & $1200^{d}$ & $986^{c}$ & $800^{\mathrm{b}}$ & $796^{\mathrm{b}}$ & $590^{a}$ & $0.09^{*}$ \\
\hline
\end{tabular}

abcde Means within same row having different superscripts were significantly different $(\mathrm{P}<0.05)$.

on $0 \%$ SOPM were significantly $(p<0.05)$ heavier than those on $5.00 \%$ and $7.50 \%$, which were also significantly heavier than birds on $10.00 \%$ SOPM. Daily weight gain followed the same trend. However feed efficiency for birds on the control diet $T_{1}$ and $T_{2}$ were most efficient and were significantly $(p<0.05)$ different from $T_{3}, T_{4}$ and $T_{5}$. Initial weights of the birds were similar $(p>0.05)$ between treatments. Though SOPM is highly nutritious, the high levels of Lectins and Proteinase (Norton, 1991 and Madubuike et al.2009) caused the reduction in weight gain as higher levels of Wheat offals were included in the diets. The observation that increasing levels of SOPM made birds consume more feed is explained by their quest to eat enough to meet their body nutritional requirement (Grant, 1999, Godoy; Batista, 1997).

The wing length and thigh length did not differ significantly $(p>0.05)$ between treatments (Table 4$)$. Birds on $0.00 \%$ SOPM were significantly $(p<0.05)$ heavier than those on $2.50 \%, 5.00 \%$ and $7.50 \%$, which were also significantly heavier than birds on $10.00 \%$ SOPM. Drum stick followed the same trend. However wing length for birds on diet $T_{3}$ and $T_{4}$ were most efficient.

In addition, Nicolakakis et al., (1999) and Ahaotu and
Ekenyem (2009) observed that higher dietary fiber depresses weight gain in broiler chickens, thus confirming the results of the experiment. Feed cost per $\mathrm{kg}$ weight gain significantly decreased $(p<0.05)$ with higher levels of SOPM. Thus considering the final weights and the cost per $\mathrm{kg}$ of weight, 50\% SOPM appears to be the optimal replacement value of wheat offal. Gizzard, proventriculus,liver, spleen, kidney and heart weights significantly increased $(p<0.05)$ with higher levels of SOPM (Table 5).

\section{Conclusion}

Sweet orange peel meal can replace wheat offal in finisher broiler rations without deleterious effect. The results on final weight, weight gain and cost per $\mathrm{kg}$ feed suggest that $50 \%$ SOPM is the optimum replacement level for wheat offal for finisher broiler production. The cost of broiler production considerably reduced with increasing levels of SOPM in the diet thus, showing the potentials for broiler production at reduced cost when SOPM is used in the formulation of finisher broiler diets. 
Table 5. Organ weights of Anak Broiler finisher birds fed varying replacement levels of sweet orange peel meal diets.

\begin{tabular}{lcccccc}
\hline \multirow{2}{*}{ Parameters } & \multicolumn{5}{c}{ Varying levels of replacement } & SEM \\
\cline { 2 - 6 } & $\mathbf{T}_{1}$ & $\mathbf{T}_{\mathbf{2}}$ & $\mathbf{T}_{\mathbf{3}}$ & $\mathbf{T}_{4}$ & $\mathbf{T}_{\mathbf{5}}$ & \\
\hline Weight of intestine (gm) & $180^{\mathrm{a}}$ & $165^{\mathrm{b}}$ & $150^{\mathrm{c}}$ & $135^{\mathrm{d}}$ & $90^{\mathrm{e}}$ & $2.96^{*}$ \\
Heart weight (gm) & $6.10^{\mathrm{a}}$ & $7.35^{\mathrm{b}}$ & $8.33^{\mathrm{c}}$ & $9.11^{\mathrm{d}}$ & $11.1^{\mathrm{e}}$ & $0.43^{*}$ \\
Gizzard and proventriculus weights (gm) & $40.1^{\mathrm{a}}$ & $45.2^{\mathrm{b}}$ & $45.1^{\mathrm{b}}$ & $60.3^{\mathrm{c}}$ & $65.4^{\mathrm{a}}$ & $0.01^{*}$ \\
Liver and spleen weights $(\mathrm{gm})$ & $20.3^{\mathrm{a}}$ & $28.9^{\mathrm{b}}$ & $30.1^{\mathrm{b}}$ & $31.3^{\mathrm{b}}$ & $35.4^{\mathrm{c}}$ & $0.39^{*}$ \\
Crop weight (gm) & $8.5^{\mathrm{a}}$ & $9.3^{\mathrm{a}}$ & $9.3^{\mathrm{a}}$ & $9.9^{\mathrm{b}}$ & $12.8^{\mathrm{b}}$ & $1.65^{*}$ \\
Kidney weight (gm) & $12.9^{\mathrm{a}}$ & $15.2^{\mathrm{b}}$ & $19.6^{\mathrm{c}}$ & $20.5^{\mathrm{c}}$ & 25.3 & $1.68^{*}$ \\
\hline
\end{tabular}

abcdeMean within same row, having different superscripts are significantly different $(P<0.05)$. ${ }^{\text {Significant. }}$

\section{CONFLICT OF INTEREST}

The authors declare that they have no conflict of interest.

\section{REFERENCES}

Aggrey, E. (2013). Dietary Replacement Value of Orange (Citrus sinesis) peels for Wheat Offals on the Performance of Broiler Finishers. HND Research Project.Imo State Polytechnic Umuagwo - Ohaji, Nigeria. 66p.

Agu P.N. (2006). Nutritional Evaluation of sweet orange (Citrus sinensis) Peel as a Feed Resource in Broiler production. Unpublished M.Sc. Thesis.Department of Animal Production, University of Agriculture, Makurdi. Benue State. Nigeria.

Ahaotu, E. O. (1999). Replacement value of Rubber seed cake for Groundnut cake on the performance of broiler chicks from 0 - 9 weeks of age. M.Sc. Thesis, Imo State University, Owerri, Nigeria. Pp. 1-5.

Ahaotu, E. O. and Ekenyem, B. U. (2009).Replacement value of feather meal for fish meal on performance of finisher Broiler chicks. Int. J. of Tropic Agric and Food sys, 3(3), 233-237.

Ahaotu, E. O., Guang - Hai, Q., Ekenyem, B. U., Korie, A. U., \& Madubuike, F. N. (2010). Replacement value of feather meal for fish meal on the performance of Starter Cockerels. Animal Production Advances, 6(1), 48-52.

Ahaotu, E. O., Ogbuokiri, U. D. E., Korie, A. U., Ekenyem, B. U., Onwuka, C. F. I., Okoli, I. C., Njoku, P. O., Ndubuisi, E. C. \& Madubuike, F. N. (2011). Effects of graded levels of pigeon pea meal on growth performance and Organ Characteristics of finisher broilers. Animal Production Research Advances. 7(2), 125-129

Ahaotu, E. O, Ehirim, V. I, Nkwocha, G. A, Iwuanyanwu, U. P., \& Ihezuo, J. P. (2012). Carcass and performance characteristics of Khaki Campbell Ducklings fed high fiber rice milling waste. Proc. $17^{\text {th }}$ Ann. Conf. Animal Science Association of Nigeria, September 9-13, Abuja. Pp. 326-329.

Ahaotu, E. O., Adeyeye S. A., \& Okonkwo, V. N. (2015). Replacement value of sweet orange (Citrus sinensis) peels for wheat offals in the performance of broiler starter diets. Scientific Journal of Animal Science. 4(3), 42-50.

Ahaotu, E. O., Okonkwo, V. N., Okorie, K. C., \& Akinfemi, A. (2016a).Effect of Bambara Nut Sievate Supplemented Exogenous Enzymes on Haematology and Serum Biochemical Value of Finisher Broiler Birds. Book of Proceedings of Academic Conference on Positioning Sub-
Saharan Africa for Development in the New Development.22$23^{\text {rd }}$ June, 2016, Cambridge Hall, University of Ghana, Legon Campus, Accra, 9(1), 32-39.

Ahaotu, E. O., Okonkwo, V. N., Ihenacho, R. A., \& Ebochuo, V. C. (2016b). Performance and Carcass Characteristics of Finisher Broilers fed Brewer's dried grain supplemented with Exogenous Enzymes. Book of Proceedings of Academic Conference on Positioning Sub-Saharan Africa for Development in the New Development.22-23 ${ }^{\text {rd }}$ June, 2016, Cambridge Hall, University of Ghana, Legon Campus, Accra, 9(1), 200-208.

AOAC (2001).Official methods of analysis.Revised edition.Association of official Analytical Chemists, Washington DC.

Baird, D. M., Allison, J. R., \& Heaton, E. K., (1974). The energy value for and influence of citrus pulp in finishing diets for swine. J. Anim. Sci., 38(3), 545-553.

Chaudry, M. A., Badshah, A., Bibi, N., Zeb, A., Ahmed, T., Ali, S., \& TerMeulen, U. (2004). Citrus waste utilization in poultry rations. Arch. Geflügelk., 68(5), 206-210.

Coloni, R. D., Lui, J. F., \& Malheiros, E. B., (2009). Citrus pulp use of the feeding of growth in rabbits. PUBVET, 3(14), 353.

Florou-Paneri, P., Babidis, V., Kufidis, D., Christaki, E., \& Spais, A. B. (2001). Effect of feeding dried citrus pulp on quail laying performance and some egg quality characteristics. Arch. Geflügelk., 65, 178-181.

Godoy, R and Batista, L. A. (1997). Study of the tannin content of forage pigeon pea (Cajanuscajan) germplasm. RevistaBrasileria - de Zooteenia, 26 (3): 443-446.

Göhl, B., (1981). Citrus by-products for animal feed. In: Ruminant nutrition: selected articles from the World Animal Review, FAO, 1981.

Gordon, S. P., \& Gordon, F. S. (2004). Contemporary statistics: A computer approach. McGraw - Hill Publishers, U.S.A.

Grant, G (1999). Metabolic and hormonal changes in rats resulting from consumption of kidney beans (Phaseolus vulgaris) or soyabean (Glycine max). Nutri. Reps. Int., 36, 763-772.

Grant, E., (2007). Citrus world. Angus Journal, Pp. 234-238.

Grueling, H. I. (2000). The Chemical analysis of tissues. Revised edition: Cornell University Press, U. S. A.

Hon, F. M., Oluremi, O. I. A. \& Anugwa, F. O. I. (2009). The effect of dried sweet orange (Citrus sinensis) fruit pulp meal on the growth performance of rabbits. Pakistan J. Nutr., 8(8), $1150-1155$.

Ipinjolu, J. K. (2000). Performance of juvenile orange koi carp 
(Cyprinuscarpio L.) fed diets supplemented with sweet orange peel meal: Body composition, nutrition, utilization and skin pigmentation. Sokoto J. Vet. Sci., 2000: 228-229.

Imo State Ministry of Lands and Survey (IMLS) (2009). Longitudes and Latitudes locations of Umuagwo, Ohaji / Egbema Local Government Area of Imo State, Nigeria.

Madubuike, F. N., Ekenyem, B. U. \& Ahaotu, E. O. (2009). Effects of dietary substitution of feather meal for fish meal on the performance of starter broilers.Anim. Product. Res. Advances. 5(1), 1-5.

Madubuike, F. N., Agiang, E. A., Ekenyem, B. U., \& Ahaotu, E. O. (2003). Replacement value of Rubber seed cake for Groundnut cake on performance of starter broilers. J. Agric and Food Sci., 1, 21-27.

Mourao, J. L., Pinheiro, V. M., Prates, J. A. M., Bessa, R. J. B., Ferreira, L. M. A., Fontes, C. M. G. A. \& Ponte, P. I. P. (2008). Effect of dietary dehydrated pasture and citrus pulp on the performance and meat quality of broiler chickens. Poult. Sci., 87, 733-743.
Nazok, A., Rezaei, M., \& Sayyahzadeh, H. (2010). Effect of different levels of dried citrus pulp on performance, egg quality, and blood parameters of laying hens in early phase of production. Trop. Anim. Health Prod., 42(4), 737-742.

Nicolakakis, I., Dotas, D., \& Imamidou, A. (1999). Digestibility and energy value of pig diets containing different levels of dried citrus pulp with enzymes. Epitheorese Zootehnikes Epistemes, 26, 43-54.

Norton, G. (1991). Proteinase inhibitors: In D'mello, J. P., Duffus, C. M., \& Duffus, J. H. (eds). Toxic substances in crop plant.Royal Society of Chemistry.Cambridge Press. U. K. Pp. 68-106.

Spackman, D. H. Stein, E. H and Moore, S. C. (1958). Automatic recording apparatus for use in the chromatography of amino acids. Analytical chemistry, 30, 1191.

Steel, R. G., \& Torrie, J. H. (1980). Principles and Procedures of Statistics: A biometrical approach. $3^{\text {rd }}$ Edition.McGraw Hill Book Coy, N.Y. U.S.A. 